\title{
Monosodium glutamate below the neurotoxic doses has no cytotoxic effect on mouse mesenchymal stem cells
}

\section{Nörotoksik dozun altındaki monosodyum glutamatın fare mezenkimal kök hücreler üzerinde sitotoksik etkisi yoktur}

\author{
Sinem Dal ${ }^{1}$, Sümeyye Arslan ${ }^{2}$, Nejat Kaan Nurol ${ }^{3}$, Tutku Göktepe ${ }^{3}$, Zehra Dilșad Çoban ${ }^{4}$, \\ Ertan Altaylı, ${ }^{4,5}$, Sefik Güran ${ }^{4,5}$
}

\author{
Erzurum Teknik Universitesi, Moleküler Biyoloj1 ve Genetik Bölümü, \\ ${ }^{2}$ Gümüşhane Üniversitesi Genetik ve Biyomühendislik Bölümü, \\ Bartın Üniversitesi, Moleküler Biyoloji ve Genetik Bölümü. \\ ${ }^{+}$Gülhane Askeri Tıp Akademisi, Tibbi Biyoloji AD \\ Sağlık Bilimleri Üniversitesi, Gülhane Tıp Fakültesi, Tıbbi Biyoloji AD. ANKARA \\ Corresponding author: Sefik Güran, Health Sciences University, Gülhane Medical Faculty, Department of Medical Biology, 06018 Etlik-Keciören \\ Ankara-TURKEY \\ E-mail: sefguran@yahoo.com \\ Received/Accepted: April 19, 2017 / July 25, 2017 \\ Conflict of interest: There is no a conflict of interest.
}

\section{SUMMARY}

Objective: Monosodium glutamate appear as a food additive that listed in the group of flavor enhancers is continuously used in various types of foods. Monosodium glutamate is the sodium salt of glutamic acid, one of the most abundant naturally-occurring non-essential amino acids. U.S. Food and Drug Administration reported that monosodium glutamate is safe for use in food. However, the excessive use of monosodium glutamate causes dizziness, nausea and vomiting. Due to reports, it causes obesity. In this study it was aimed to find out the cytotoxicity of monosodium glutamate and the role on the selected genes, which have role on obesity.

Method: In our study, mice were used which are known to be the most sensitive in terms of toxicity. The cytotoxic effects of monosodium glutamate on mouse mesenchymal stem cells at monosodium glutamate doses below the blood dose (100$130 \mu \mathrm{mol} / \mathrm{dl}$ ) that reported as the neuronal damage threshold in mice were studied. Furthermore leptin-lep and ghrelin / obestatin in prepropeptide-GHRL gene expressions in order to find out the role of monosodium glutamate in obesity were analyzed.

Results: Monosodium glutamate below the toxic dose does not have a cytotoxic effect on mouse mesenchymal stem cells. Also no expression change in applied monosodium glutamate doses was observed in genes which are known to be associated with obesity.

Conclusions: Our results support that monosodium glutamate has no toxic effect on stem cells in uses in certain doses. Keywords : Monosodium glutamate, mouse mesenchymal stem cells, leptin gene, ghrelin/obestatin prepropeptide gene.

ÖZET

Amaç: Monosodyum glutamat lezzet arttırıcılar grubunda gıda katkı maddesi olarak çeşitli yiyeceklerde kullanılmaktadır. Monosodyum glutamat glutamik asidin sodyum tuzudur ve doğal yollarla en fazla oluşan esansiyel olmayan aminoasitlerden biridir. Amerikan Gıda Ve İlaç Teşkilatı (U.S. Food and Drug Administration) monosodyum glutamatın gıdada kullanımının güvenli olduğunu bildirmiştir. Ancak aşırı kullanımında baş dönmesi, bulantı kusma yapmaktadır. Makalelerde obeziteye neden olduğu bildirilmektedir. Bu çalışmada, monosodyum glutamatın sitotoksik ve obezitede rolü olan seçilmiş bazı genlere olan etkilerinin bulunması amaçlanmıştır.

Yöntem: Çalışmamıza toksisite yönünden en hassas organizma olduğu bilinen fareler alınmıştır. Monosodyum glutamatın fare mezenkimal hücreler üzerine olan sitotoksik etkisi farelerde nöronal hasar oluşturduğu bildirilen kan dozunun (100-130 $\mu \mathrm{mol} / \mathrm{dl})$ altındaki dozlar kullanılarak çalışılmıştır. Ayrıca monosodyum glutamatın obezite üzerine 
olan etkisini bulmak için "leptin-lep" ve "Ghrelin/Obestatin Prepropeptide-GHRL" genlerine ait ekspresyon değișikliklerine bakılmıștır.

Bulgular: Monosodyum glutamatın toksik dozun altında fare mezenkimal kök hücre üzerinde bir sitotoksik etkisi olmadığı bulunmuş̧ur. Uygulanan monosodyum glulatamat dozlarında hücrede obezite ile ilgili olduğu bilinen genlerin ekspresyonlarını değiștirmediği saptanmıştır.

Sonuç: Sonuçlarımız monosodyum glutamatın gıdada belli dozlarda kullanımının kök hücreler üzerine toksik bir etkisi olmadığını destekler niteliktedir.

Anahtar sözcükler: Monosodyum glutamat, fare mezenkimal kök hücresi, leptin geni, ghrelin/obestatin prepropeptide geni

\section{INTRODUCTION}

Monosodium glutamate (MSG) is used in the food industry as a flavor enhancer that has a distinct taste called umami (which is also known as the fifth basic taste) that intensifies the meaty, savory flavor of food, as naturally occurring glutamate does in foods such as stews and meat soups ${ }^{1}$. It is licensed as E 261 in the E list of food additives (European Union) and the usage of glutamic acid and its salts in any type of food product is referred as $10 \mathrm{mg} / \mathrm{kg}$ of food substance, at the same time the use of MSG in spices and seasonings is stated as QS "quantum satis" (literally the amount which is enough) in Turkish Food Codex (Türk Gida Kodeksi, Renklendiriciler ve Tatlandırıcılar Dışındaki Gıda Katkı Maddeleri Tebliği). The U.S. Food and Drug Administration (FDA) announced that MSG is in "generally recognized as safe - GRAS". Despite of these, large doses of MSG can cause headaches and other feelings of discomfort ${ }^{2}$. The European Union classifies it as a food additive permitted in certain foods and subject to quantitative limits ${ }^{3}$. A popular belief in the World, known as "Chinese restaurant syndrome", is that large doses of MSG can cause headaches and other feelings of discomfort, but scientists have been unable to trigger such reactions in controlled studies ${ }^{4}$. Studies exploring MSG's role in obesity have yielded mixed results ${ }^{5,6}$. It is being implicated for varied pathological condition like obesity, gonadal dysfunction, learning difficulty etc. ${ }^{7}$. So we decided to find out the cytotoxic role of MSG on cell culture. Mouse mesenchimal stem cells were chosen for their sensitivity to toxicity ${ }^{8}$. Also, the expressions of selected genes which have roles on obesity were analyzed in our panel ${ }^{9,10}$.

As generally known, mesenchymal stem cell (MSC) is a type of adult stem cell derived from bone marrow that is currently being used clinically for tissue regeneration and for their immunomodulatory and trophic effects ${ }^{11}$. It is a prototypical adult stem cell with capacity for selfrenewal and differentiation with a broad tissue distribution (eg. Bone marrow, adipose tissue). The endogenous role for MSCs is maintenance of stem cell niches (classically the hematopoietic), and as such, MSCs participate in organ homeostasis, wound healing, and successful aging ${ }^{12}$. So, MSC generally uses in cytototoxicity experiments as a model ${ }^{13,14}$.

As a hormone, leptin is produced by adipose cell that helps to regulate energy balance by inhibiting hunger. It plays a major role in the regulation of body weight. This protein, which acts through the leptin receptor, functions as part of a signaling pathway that can inhibit food intake and/or regulate energy expenditure to maintain constancy of the adipose mass. This protein also has several endocrine functions, and is involved in the regulation of immune and inflammatory responses, hematopoiesis, angiogenesis and wound healing ${ }^{15}$. Leptin is opposed by the actions of the hormone ghrelin ${ }^{16}$. Ghrelin is a powerful appetite stimulant and plays an important role in energy homeostasis. Its secretion is initiated when the stomach is empty, whereupon it binds to the growth hormone secretagogue receptor in the hypothalamus which results in the secretion of growth hormone (somatotropin). Ghrelin is thought to regulate multiple activities, including hunger, reward perception via the mesolimbic pathway, gastric acid secretion, gastrointestinal motility, and pancreatic glucose-stimulated insulin secretion ${ }^{17}$. Both hormones act on receptors in the arcuate nucleus of the hypothalamus to regulate appetite to achieve energy homeostasis. In obesity, a decreased sensitivity to leptin occurs, resulting in an inability to detect satiety despite high energy stores ${ }^{9,10}$.

So, the cytotoxic effect of MSG was analyzed on mouse mesenchimal stem cells in our panel. Also gene expression alteration was analyzed on leptinlep (Omim No: 164160) and ghrelin/obestatin prepropeptide-GHRL (Omim No: 605353) genes with MSG application. No cytotoxicity was found on mouse MSCs due to XTT 2,3-Bis-(2-Methoxy4-Nitro-5-Sulfophenyl)-2H-Tetrazolium-5-

Carboxanilide) analyses result. Also the gene expression analyses of leptin- and ghrelin genes revealed no extra changes in human MSC with MSG. 


\section{MATERIAL AND METHODS}

This study was prepared according to the ethical decisions obtained from Gülhane Military Medical Academy, Health Sciences Institute (GATA-Etik2012-4 and 7).

Cell culture procedure of mouse MSC: In this study, MSCs were used obtained from in a previous study from two Balb $\mathrm{C}$ mice ${ }^{18}$. In the isolation and culture procedures of mouse MSCs, Lennon and Caplan's methodology was used, with minor modifications ${ }^{19}$. Cells were incubated in RPMI82261640 (Sigma-Aldrich-R8758) including $10 \%$ (v/v) FBS (Biochrom AG, Germany) and 1\% (v/v) penicillin and streptomycine (Biological Industries, Israel) $\quad\left(37^{\circ} \mathrm{C}, \quad 5 \% \quad \mathrm{CO}_{2}\right) \quad$ (Heraus incubator, Henau, Germany).

Preparing MSG solution: MSG (Alfasol ${ }^{\circledR} 1 \mathrm{~g} / \mathrm{kg}$ $250 \mathrm{~g}$ ) was prepared as solution in $10,30,60,90$ $\mu \mathrm{mol} / \mathrm{dl}$ concentrations which are less than the threshold blood levels associated with neuronal damage in the mouse ${ }^{8}$.

Cell viability assay: Trypan blue (Sigma Aldrich Co. 302643) was used as a stain in procedures for viable cell counting. Trypan blue was diluted at 0.8 $\mathrm{mM}$ in PBS. It was mixed with the cells $1: 1$. In this method, live (viable) and dead (non-viable) cells were counted on hemocytometer ${ }^{20}$.

MTT Cell Proliferation Assay: For the cell viability, the cell cultures were analyzed with MTT (3-[4,5-dimethylthiazol-2-yl]-2,5-

diphenyltetrazolium bromide; thiazolyl blue) after incubating for 24 hours with different concentrations of MSG. According to the instruction manual MTT cell proliferation assay was used on human MSCs. In each cell culture flask, there were $3 \times 10^{4}$ cells. After 24 hour, different concentrations of MSG were added and MTT assay was performed ${ }^{21}$.
RNA Isolation Procedure: RNA isolation was performed from the examples of mouse MSCs treated with MSG in $90 \mu \mathrm{mol} / \mathrm{dl}$ concentrations. Four group samples were used (control group and 48-hour group). In each group, three different samples were taken. RNA isolations were performed in each sample (Roche RNA isolation kit).

cDNA Synthesis and Gene Expression Analyses: All RNAs were performed for cDNA synthesis (Revert Aid cDNA synthesis kit). The quality of cDNA's were controlled on $2 \%$ agarose gel. In gene expression analyses, reverse transcription polymerase chain reaction (RT-PCR) was used. Forward and reverse primers were designed from Primer Bank for leptin, ghrelin/obestatin prepropeptide and $\beta$ actin (for control) genes. RTPCR conditions: $95^{\circ} \mathrm{C}$ for $10^{\prime},, 56^{\circ} \mathrm{C}$ for $15^{\prime},, 72^{\circ} \mathrm{C}$ for 15' - 45 cycle (Roche Light Cycler1.5). Each reaction was performed as $20 \mu 1(10 \mu 12 \mathrm{x}$ SYBR,

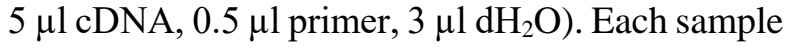
was studied for 8 times for the sake of proper statistical results. Results were analyzed by "Roche Light Cycler1.5 software".

Statistical Analyses: For the LD50 values according to MTT results, the LC50 nomination method was used. For evaluating the results of RTPCR analyses, Student's t test (one sample $t$ test) was used for two-group comparisons by using SPSS. Values are mean \pm sd unless otherwise indicated.

\section{RESULTS}

In our study, monosodium glutamate solutions were used below the toxic dose in mouse neuron degeneration ${ }^{8}$. MSG solutions in 10, 30, 60, 90 $\mu \mathrm{mol} / \mathrm{dl}$ concentrations were used in cell culture for finding the role of MSG in mouse MSCs "in vitro". In our experiments most of the cells (at least 70\% of cells) were found viable in culture flasks due to cell viability assay results. In MTT analyses, no cytotoxicity was observed in mouse MSC with MSG application in certain concentrations (Table 1). As a control, untreated flasks with mouse MSCs were used in MTT analyses and RT-PCR analyses. 
Table 1. XTT assay results of MSG solutions in our analyses.

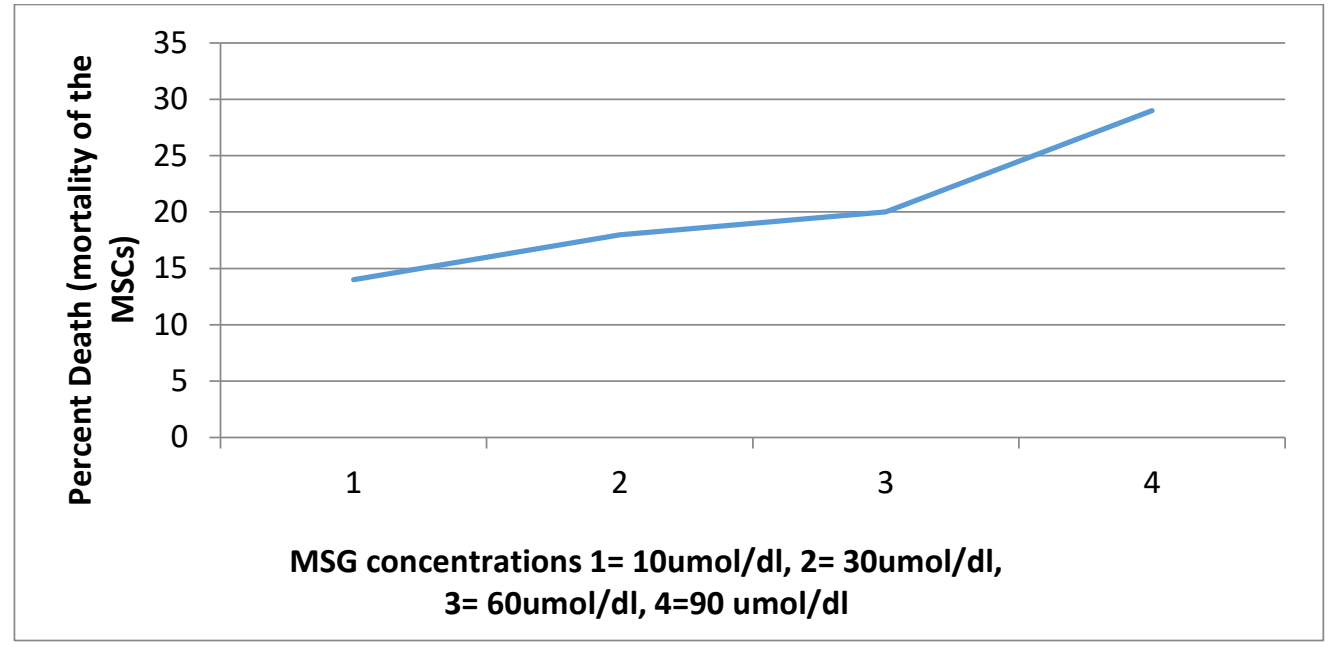

Gene expression analyses results revealed no statistical difference in control and studied groups in leptin and ghrelin genes ( $\mathrm{p} \geq 0.05)$. In control group, leptin gene expression was found as
$3,31 \times 10^{-3}$ fold. In treated with $90 \mu \mathrm{mol} / \mathrm{dl} \mathrm{MSG}$ group, leptin gene expression was found as similar as in control group $\left(3,70 \times 10^{-3}\right)$ (Table2).

Table 2. The gene expression analyses results of leptin and ghrelin genes. Th results revealed no statistical difference in control and studied groups.

\begin{tabular}{|c|c|c|c|}
\hline Genes & $\begin{array}{c}\text { Mouse MSCs } \\
\text { untreated with MSG }\end{array}$ & $\begin{array}{c}\text { Mouse MSCs treated with 90 } \\
\text { Mmol/dl MSG }\end{array}$ & $\begin{array}{c}\text { Student t tests results } \\
\text { (P values) }\end{array}$ \\
\hline leptin & $3,31 \times 10^{-3} \pm 0.03$ & $3,70 \times 10^{-3} \pm 0,94$ & $\mathrm{p} \geq 0.05$ \\
\hline ghrelin & $1,51 \times 10^{-4} \pm 0.33$ & $1,69 \times 10^{-4} \pm 0.99$ & $\mathrm{p} \geq 0.05$ \\
\hline
\end{tabular}

Similar results were obtained in ghrelin gene expression results. In control group, $1,51 \times 10^{-4}$ fold gene expression result was found. Despite of this finding, $1,69 \times 10^{-4}$ fold gene expression result was found in treated with $90 \mu \mathrm{mol} / \mathrm{dl}$ MSG group (Table 2). Due to gene expression results, no effect of MSG was found in leptin and ghrelin genes in mouse MSCs.

\section{DISCUSSION}

MSG has been used for more than 100 years to season food, with a number of studies conducted on its safety. Consumption and manufacture of highsalt and high-glutamate foods, which contain both sodium and glutamate, dates back far longer, with evidence of cheese manufacture as early as $\mathbf{5 5 0 0}$ $\mathrm{BC}^{22}$. International and national bodies governing food additives currently consider MSG safe for human consumption as a flavor enhancer ${ }^{23}$. Under normal conditions, humans can metabolize relatively large quantities of glutamate, which is naturally produced in the gut by exopeptidase enzymes in the course of protein hydrolysis. The median lethal dose (LD50) is between 15 and 18 $\mathrm{g} / \mathrm{kg}$ body weight in rats and mice, respectively, five times greater than the LD50 of salt $(3 \mathrm{~g} / \mathrm{kg}$ in rats) ${ }^{24}$. The threshold blood levels associated with neuronal damage in the mouse (most sensitive species) are $100-130 \mu \mathrm{mol} / \mathrm{dl}$ in neonates rising to $>630 \mu \mathrm{mol} / \mathrm{dl}$ in adult animals. In humans, plasma levels of this magnitude have not been recorded even after bolus doses of $150 \mathrm{mg} / \mathrm{kg}$ body wt (ca. $10 \mathrm{~g}$ for an adult). Additionally, studies in infants have confirmed that the human baby can metabolize glutamate as effectively as adults ${ }^{8}$. The use of MSG as a food additive and the natural level of glutamic acid in foods are not toxicological concerns in humans ${ }^{24}$. The FDA has classified MSG as a food ingredient that is "generally recognized as safe-GRAS" but its use remains controversial. For this reason, when MSG is added to food, the FDA requires that it be listed on the label ${ }^{23}$. In excess uses, some symptoms had been reported including headache, flushing, sweating, rapid, fluttering heartbeats (heart palpitations), chest pain, nausea and weakness ${ }^{23,24}$. Also obesity 
was reported 10,25 . In a recent publication, the behavioral and neurochemical effects of MSG were analyzed in various and subsequent dosages on male Wistar rats during the neonatal period. The injections of MSG affect on the neurochemical parameters, learning memory, and locomotor activities of rats ${ }^{26}$. In an other publication, the effects of adding of monosodium glutamate (MSG) to a standard diet on oxidative stress in kidney, nitric oxide excretion, renal ions handling and blood pressure were found. The results indicate that the addition of MSG in the diet decreases the excretion of $\mathrm{Na}, \mathrm{K}$ and water with hyperfiltration. $\mathrm{NaCl}$ retention that leads to hypertension was accompanied by renal pathologic changes, intrarenal oxidative stress and reduction of nitric oxide excretion ${ }^{27}$.

In non toxic doses stated in the literature, the cytotoxic effect of MSG was analyzed on mouse MSCs in our experiment. In cell viability assay results, most of the cells were found alive (at least $70 \%$ of cells) (Table 1). In MTT analyses, no cytotoxicity was found. These results support literature findings. MSG seems as safe in usage of certain concentrations on stem cell toxicity also.

Leptin is mainly secreted by white adipose tissue and regulates energy homeostasis by inhibiting food intake and stimulating energy expenditure through its action in neuronal circuits in the brain, particularly in the hypothalamus. However, hyperleptinemia coexists with the loss of responsiveness to leptin in common obese conditions. Diseases associated with LEP gene include obesity, morbid, due to leptin deficiency and morbid obesity. Among its related pathways, leptin affects on JAK/STAT and MAPK cascades $^{28,29}$. Ghrelin is a metabolic hormone that promotes energy conservation by regulating appetite and energy expenditure. Although some studies suggest that antagonizing ghrelin function attenuates body weight gain and glucose intolerance on a high calorie diet, there is little data on the metabolic actions of ghrelin in the obese state. Ghrelin affects on peptide ligand-binding receptors and RET signaling. In a recent manuscript, the role of ghrelin and ghrelin signaling in aging was discussed. As known, calorie restriction delays aging, reduces mortality, and extends life. Ghrelin, which is secreted during fasting, is well known as an orexigenic peptide. Because ghrelin is increased by caloric restriction, ghrelin may play an important role in the mechanism of longevity mediated by calorie restriction $^{30}$, 31. In analyses of these two gene expression, no obvious chance was observed in control and MSG treatment in mouse MSCs (Table
2). So, no effect of MSG was found in such kind of stem cell for the expression of leptin and ghrelin genes in our experiments.

Finally, in certain doses MSG seems non-toxic in stem cells in mouse. Further analyses must be carried out also in human to support the findings of this study.

\section{REFERENCES}

1. Yamaguchi S. Basic properties of umami and effects on humans. Physiology \& Behavior 1991; 49: 833-41.

2. Kurihara K. Glutamate: from discovery as a food flavor to role as a basic taste (umami)? The American Journal of Clinical Nutrition 2009; 90: 719-22.

3. Tarasoff L, Kelly MF. Monosodium Lglutamate: a double-blind study and review. Food Chem. Toxicol 1993; 31: 1019-35.

4. Yamaguchi S. Basic properties of umami and effects on humans. Physiology \& Behavior 1991; 49: 833-41.

5. Shi Z, Luscombe-Marsh ND, Wittert GA, Yuan B, Dai Y, Pan X, Taylor AW. Monosodium glutamate is not associated with obesity or a greater prevalence of weight gain over 5 years: Findings from the Jiangsu Nutrition Study of Chinese adults. Br J Nutrition 2010; 104: 457-63.

6. Jin YJ, Cao PJ, Bian WH, Li ME, Zhou R, Zhang LY, Yang MZ. BDNF levels in adipose tissue and hypothalamus were reduced in mice with MSGinduced obesity. Nutr Neurosci 2015; 18: 376-82.

7. Bhattacharya T, Bhakta A, Ghosh SK. Long term effect of monosodium glutamate in liver of albino mice after neo-natal exposure. Nepal Med Coll J 2011; 13: 11-6.

8. Walker R. The significance of excursions above the ADI. Case study: monosodium glutamate. Regul Toxicol Pharmacol 1999; 30(2 Pt 2): 119-21.

9. Brennan AM, Mantzoros CS. Drug Insight: the role of leptin in human physiology and pathophysiology--emerging clinical applications. Nat Clin Pract Endocrinol Metab 2006; 2: 318-27.

10. Pan H, Guo J, Su Z. Advances in understanding the interrelations between leptin resistance and obesity. Physiology \& Behavior 2014; 130: 15769.

11. Zhang L, Peng LP, Wu N, Li LP. Development of bone marrow mesenchymal stem cell culture in vitro. Chin Med J (Engl) 2012; 125: 1650-5. 
12. Williams AR, Hare MJ, Dimmeler S, Losordo D. Mesenchymal Stem Cells, Biology, Pathophysiology, Translational Findings, and Therapeutic Implications for Cardiac Disease. Circulation Research. 2011; 109: 923-40.

13. Alkahtani A, Alkahtany SM, Anil S. An in vitro Evaluation of the Cytotoxicity of Varying Concentrations of Sodium Hypochlorite on Human Mesenchymal Stem Cells. J Contemporary Dental Practice 2014; 15: 473-81.

14. Jeonga JY, Suresha S, Park MN, Jang M, Park S, Gobianand K, You S, Yeon SH, Lee HJ. Effects of Capsaicin on Adipogenic Differentiation in Bovine Bone Marrow Mesenchymal Stem Cell. Asian-Australasian J Animal Sci 2014; 27: 178393.

15. Ottaway N, Mahbod P, Rivero B, Norman LA, Gertler A, D'Alessio DA, Perez-Tilve D. Dietinduced obese mice retain endogenous leptin action. Cell Metab 2015; 21: 877-82.

16. Cui H, López M, Rahmouni K. The cellular and molecular bases of leptin and ghrelin resistance in obesity. Nat Rev Endocrinol 2017; 13: 338-51.

17. Bali A, Jaggi AS. An Integrative Review on Role and Mechanisms of Ghrelin in Stress, Anxiety and Depression. Curr Drug Targets 2016; 17: 495507.

18. Çoban ZD, Güzel H, Demircan A, Arslan M, Demirhan FS, Karaağaç N, Babayiğit N, Öveç M, Sönmez E, Kaynak M, Bal R, Yurdakul M, Satman M, Ada MF, Akyüz TZ, Ceylan MM, Daştan A, Farhmand N, Güran Ş. Mesenchymal stem cells obtained from mouse represents high viability and steamness properties in the early phase of cell culture. Gülhane Medical Journal (in press).

19. Lennon DP, Caplan AI. Isolation of human marrow-derived mesenchymal stem cells. Exp Hematol 2006; 34: 1604-05.

20. Coco-Martin JM, Oberink JW, van der Veldende Groot TA, Beuvery EC. Viability measurements of hybridoma cells in suspension cultures. Cytotechnology 1992; 8: 57-64.

21. Çoban ZD, Avcu F, Ural AU, Kuzhan O, Güran Ş. The sitotoxic effect of gemcitabine on multiple myeloma (RPMI-8226) and Ig G plasma cell leukemia (ARH 77) cell lines Gulhane Medical Journal 2012; 54: 263-6.

22. Salque M, Bogucki PI, Pyzel P, SobkowiakTabaka I, Grygiel R, Szmyt M, Evershed RP. Earliest evidence for cheese making in the sixth millennium bc in northern Europe. Nature 2013; 493: 522-5.

23. Ikeda K. New seasonings. Chem Senses 2002; 27: 847-9.

24. Tarasoff L, Kelly MF. Monosodium Lglutamate: a double-blind study and review. Food Chem Toxicol 1993; 31: 1019-35.

25. Pelantová $\mathrm{H}$, Bártová $\mathrm{S}$, Anýž $\mathrm{J}$, et al. Metabolomic profiling of urinary changes in mice with monosodium glutamate-induced obesity. Anal Bioanal Chem 2016; 408: 567-78.

26. Çetin Kardeşler A, Başkale E. Investigation of the behavioral and neurochemical effects of monosodium glutamate on neonatal rats. Turk $\mathbf{J}$ Med Sci 2017 12; 47:1002-11.

27. Contini MDC, Fabro A, Millen N, Benmelej A, Mahieu S. Adverse effects in kidney function, antioxidant systems and histopathology in rats receiving monosodium glutamate diet. Exp Toxicol Pathol 2017 May 15. pii: S0940-2993(16)30333-5. doi: 10.1016/j.etp.2017.03.003.

28. Aragonès G, Ardid-Ruiz A, Ibars M, Suárez M, Bladé C. Modulation of leptin resistance by food compounds. Mol Nutr Food Res 2016 Feb 4. doi: 10.1002/mnfr.201500964.

29. Hopkins BD, Goncalves MD, Cantley LC. Obesity and Cancer Mechanisms: Cancer Metabolism. J Clin Oncol. 2016; 34: 4277-83.

30. Zigman JM, Bouret SG, Andrews ZB. Obesity Impairs the Action of the Neuroendocrine Ghrelin System. Trends Endocrinol Metab 2016; 27: 54-63.

31. Amitani M, Amitani H, Cheng KC, Kairupan TS, Sameshima N, Shimoshikiryo I, Mizuma K, Rokot NT, Nerome Y, Owaki T, Asakawa A, Inui A. The Role of Ghrelin and Ghrelin Signaling in Aging. Int J Mol Sci 2017 12; 18. pii: E1511. doi: 10.3390/ijms18071511. 